\title{
ESSAY
}

\section{Black Miami to Me}

\author{
Tera Hunter \\ Princeton University, US \\ thunter@princeton.edu
}

Tera Hunter reflects on growing up Black in Miami and how it has shaped her intellectual pursuits.

Keywords: African American; migration; Allapattah; El Portal; middle class

Miami is home to me. But to nearly everyone I meet, especially in academia, it always seems like an exotic place, based perhaps on images of South Beach. People tend to have a hard time placing me as a person who is black and grew up in Miami. People north of the Florida border often say, "You don't look like or sound like someone from Miami. I don't know anyone who actually grew up there. What was it like?" Most are perplexed by the absence of what they consider a clear "accent" in my voice, whatever that might mean, to signal my place of origin in the world. Implicit in these questions is an understanding of Miami as "different," "other," and not a "normal" place to grow up-especially as a black person. These questions also express a curiosity to know where Miami fits along the spectrum of regional cities. People usually assert that it is not Southern, but if you grow up black in Miami, you know how deeply Southern it is. Yet, it also is very Caribbean, more polyglot than traditional Southern cities, more than the black vs. white binary could describe.

My childhood was spent in primarily two neighborhoods: Allapattah, which then was the southern edge of Liberty City, and El Portal, on the edge of Miami Shores. ${ }^{1}$ While I lived principally in two neighborhoods, I inhabited many parts of the city because of the activities that I participated in, and because of the different schools I attended outside of my local district.

Both of my parents migrated from the rural South, from small towns in northeast Georgia. Like many African Americans, eager to escape small towns for a better life, they were a part of the late years of the Great Migration. My dad's uncle and aunt had moved to Miami in the 1940s and my father followed in 1955, drawn by the prospects of good jobs and the desire to escape the strictures of the rural Jim Crow. He did a tour in the Army and then married my mother in 1959, who followed him there. I was born in the maternity ward of the privately-owned black clinic run by Dr. Carl E. Yeager, Jr. (and his father) in 1960, which was close to the neighborhood that my parents rented an apartment in the heart of Liberty City. They formed a community there that would continue to be part of their closely-knit friend circle even after they and others moved out. By the time I was two or three, they bought a house two blocks away from Allapattah Elementary School, which me and my brother attended. At the time, my dad was a longshoreman and would later become the Vice President of the union. My mother was a stay-at-home mom during my early years, but she would later return to school to finish her degree and become a Special Education teacher.

The block where I spent my early childhood represented a microcosm of black Miami. The houses were a diverse array of mostly modest bungalows, though there were a few more interesting Florida ranch style homes too. When my parents moved there, the neighborhood was in transition racially, as whites were moving out or had already moved away. By the time I was aware of things, I can recall there was only one white woman who lived alone on the block.

\footnotetext{
${ }^{1}$ Today Allapattah and Liberty City are two distinctly different neighborhoods. The former is considered home to Latinx immigrants and migrants and the latter a distinctly Black enclave.
} 


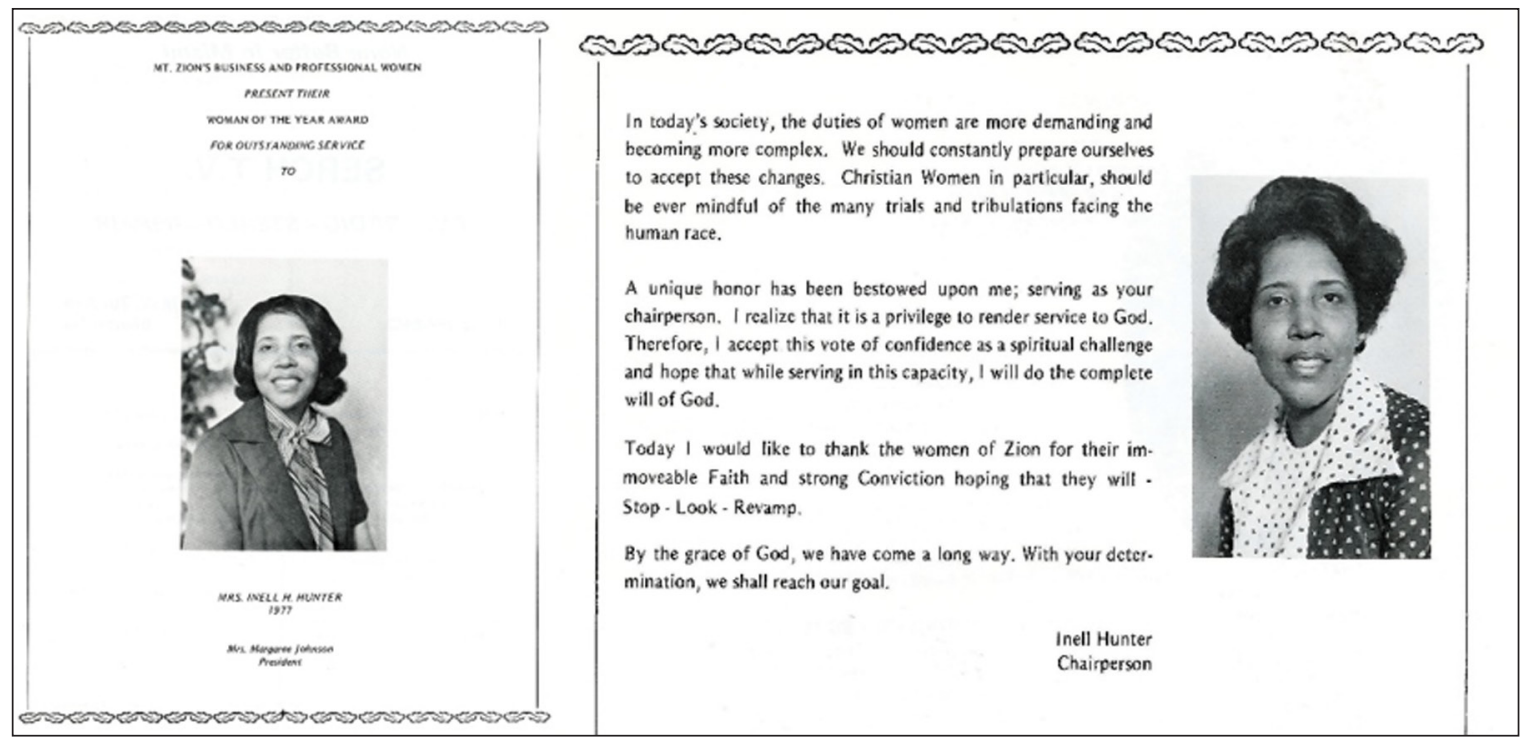

Mrs. Inell Hunter, Tera Hunter's mother, selected in 1977 as Woman of the Year at Mt. Zion Baptist Church. Photo courtesy of The Black Archive.

The class composition of my block also reflected the kinds of neighborhoods encountered in a very racially segregated city. The occupations of the adults were wide ranging: a dentist, business owners, chef, teachers, nurses or nurse aids, and blue collar employment of various kinds. Most of the homes were occupied by married parents with children. There were exceptions. One house held three generations of women and a girl, the Campbells and Browns: grandmother, mother, and daughter-and then eventually the latter's son-and for a while a second husband of the mother. Another home was inhabited by two generations: an adult single man owned the home and his elderly parents lived with him, the Tuckers. If my mother was not at home when we arrived from school, my siblings and I spent the most time under their adult supervision in their multigenerational home. Here I was introduced to "soap operas," what the older couple referred to as "the stories," and which I enjoyed watching for a long time after. Replicating familiar foods and farming activities from their earlier experiences living further north in the state, they grew sugarcane in their backyard, which they shared with neighbors, along with other vegetables and fruits.

One of the two best houses on the block was owned by an older couple, Mr. and Mrs. Jones, who had adult children who lived elsewhere. They both "worked on Miami Beach" in the homes of whites, as I recall, as a domestic worker and driver. Their house sat on one of the larger lots with a nice expanse of immaculately cultivated back and front yards. And inside, the house was carefully, artfully decorated, probably in styles that were very similar to the homes in which the couple worked on Miami Beach. We have a very blurred photograph, taken by my father, of my siblings, my mother, and I at this family's home around 1968, posing with Alberta Williams King, mother of Martin Luther King, Jr. Mrs. King was staying with the couple while she was a guest at the their Overtown church. The options for staying in hotels was fairly limited aside from the few black owned hotels, like Carver located in Overtown, although white hotels were desegregated in the 1950s. Still, even the most distinguished black guests visiting the city often preferred the comfort of staying in the "nice homes" of black families, rather than risk racial insult.

The other striking house on our block, what I would now recognize as mid-century modern, was owned by the bachelor dentist, Dr. Atkinson. He seemed to live alone for a long time before marrying "late" in life-or what I considered "late in life" as a child. He was like the cool uncle on the block-but not the creepy kind. He drove a fancy convertible sports car, and he would occasionally give the neighborhood kids rides when he went on errands. He kept his freezer filled with popsicles and ice cream for us. Needless to say, he was much beloved, so you can imagine that we all felt a little jealous when he finally did marry and had less time for the neighborhood kids.

For preschool, I attended Jackson's Toddle Inn, a privately-owned black school that included pre-K through primary grades. It was not close to my house and I recall being picked up in a school van to attend. The student body was diverse in terms of socio-economic class, but I recall, even as a tiny person, having a sense of some differences among the families. The black elite, doctors and lawyers (or whatever that meant at the 


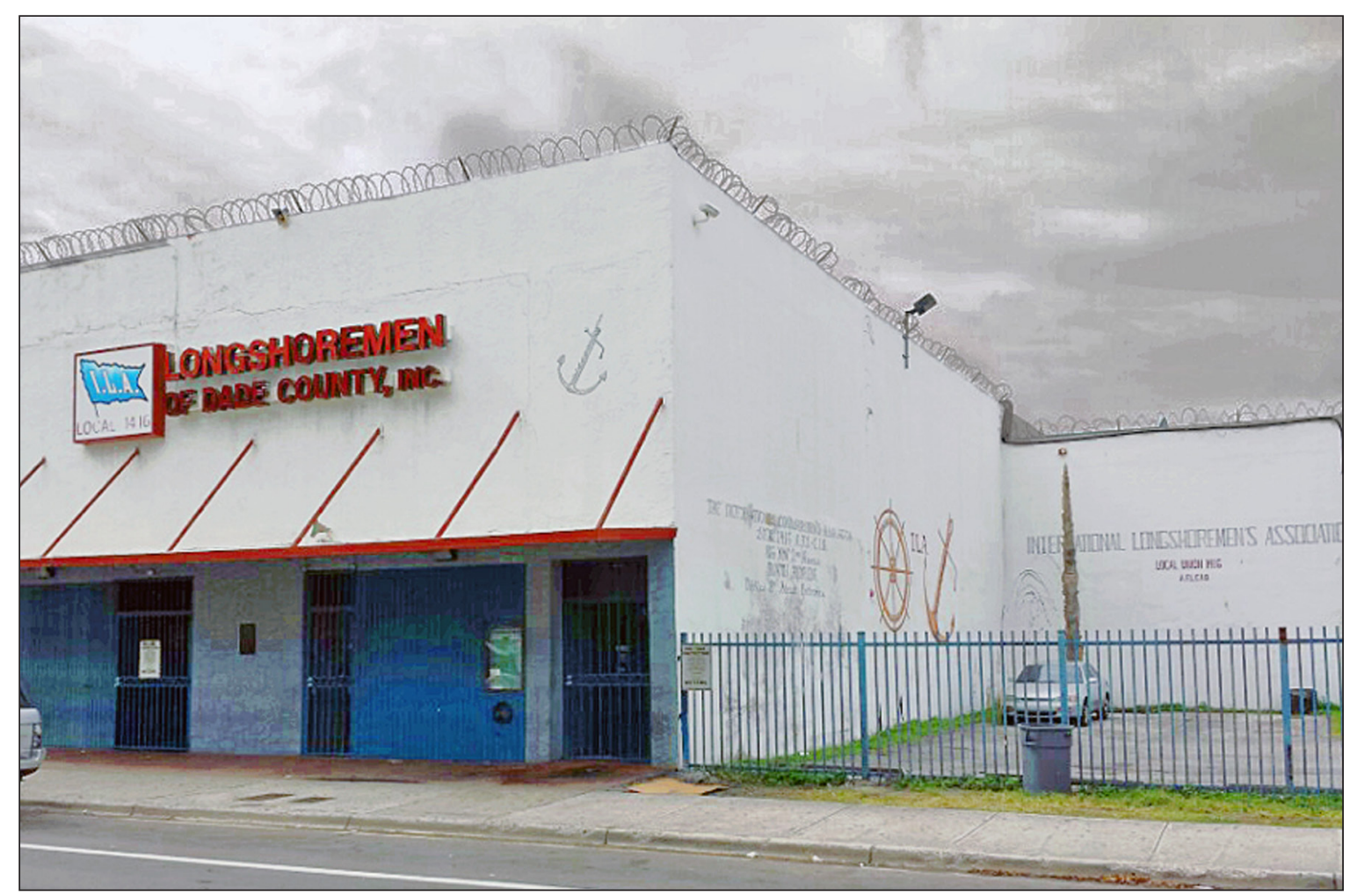

Headquarters of the International Longshoremen's Association Local 1416, chartered in Overtown in 1936.

time in Miami) sent their kids there. I came to understand this through a conversation that I had with my mother about one of the popular annual events at the school. At the event, two kids would be crowned king and queen, but the event had a fund-raising component. And from my memory of what my mother told me, the kids who won and were crowned king and queen were those who raised the most money-meaning those whose parents had the most money to give. My mother told me I wouldn't be in that competition.

I then attended Allapattah Elementary School for $1^{\text {st }}$ through $5^{\text {th }}$ grades. I could walk to school and did so on my own with my brother and friends. It seemed to me at the time that my mother was at the school frequently, sometimes appearing unannounced, because she was involved in the PTA. I loved my teachers, all of whom were black women until the $5^{\text {th }}$ grade. Mrs. Bryant, my third grade teacher, was the only one who lived not too far away. The others, like Miss Speight, my first grade teacher, inhabited my larger community.

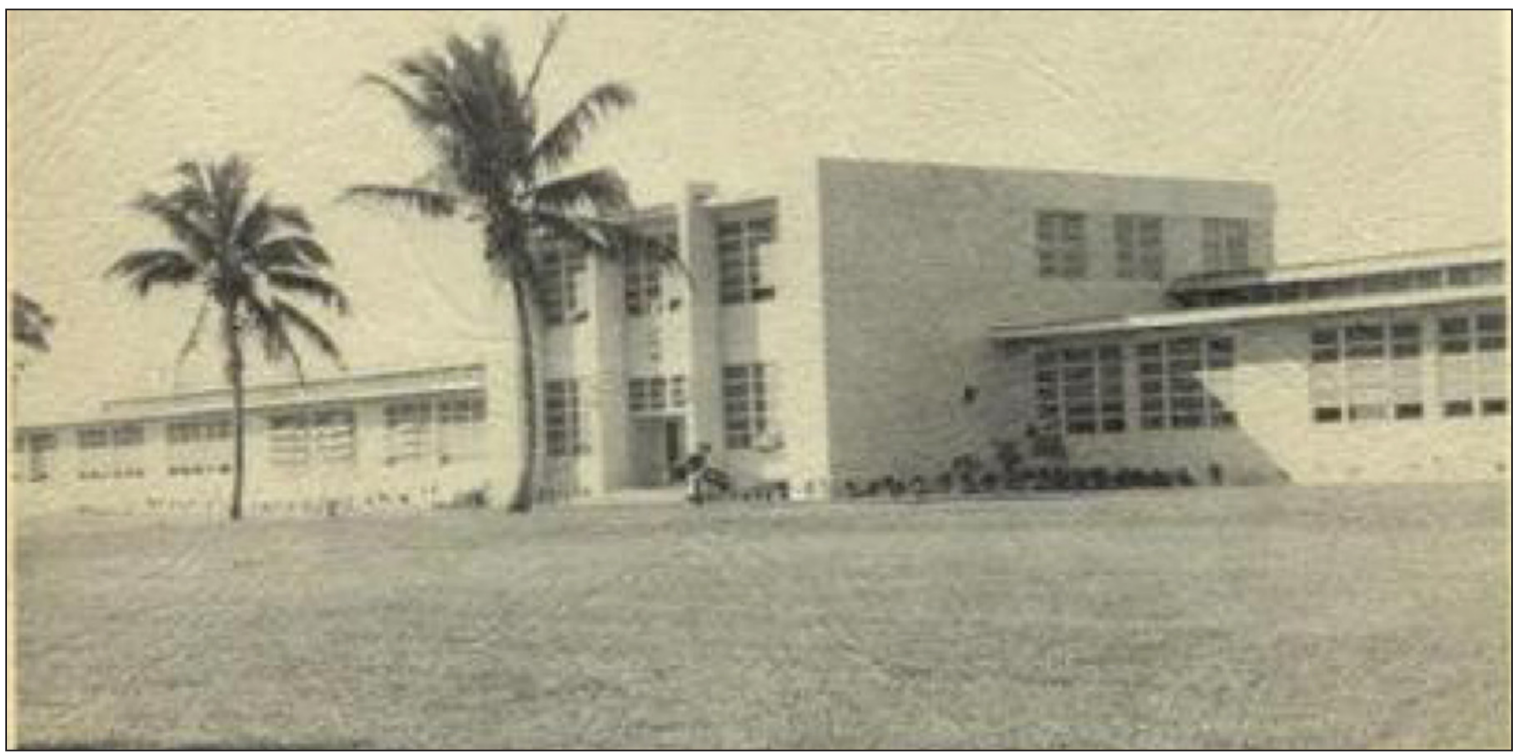

Allapattah Elementary School circa 1960. 
Elementary school intrigue among the kids was generated by the giddy conversations between Speight and one of the male teachers. They would later marry, we discovered to our delight. In $5^{\text {th }}$ grade the teaching staff was integrated, and, Miss Camden, the new $5^{\text {th }}$ grade teacher was a white woman, whom I liked as well. She invited me and a group of other fifth grade girls over for dinner, which felt like a very grown up thing to do, so our parents drove us to her house-down south somewhere-and dropped us off for our dinner party, where she introduced us to fondue.

Instead of attending the local junior high for $6^{\text {th }}$ through $8^{\text {th }}$ grades, my parents decided to transfer me out of the neighborhood school. The neighborhood school, Allapattah Junior High, was already getting a bad reputation. I went first to Kensington Park Elementary on Northwest 30th Avenue and then to Kinloch Park Junior High. Both of these schools were predominantly white, though also had a sizeable number of Cuban Americans as Little Havana was growing. My two best friends and I were among the few black kids there. I made friends with some of the white girls through baton twirling in $6^{\text {th }}$ grade. One of the girls I was closest to (who later performed with the Dolphin Dolls at the halftime shows at NFL football games) came from a very modest family. I visited her house for baton practice, but she never ventured to my distant neighborhood. Where I really liked Michael Jackson, she was totally in love with Donny Osmond, to the point that she had an elaborate fantasy life with him. I think she picked me out early to befriend because I was one of the new kids in school. I'm sure everyone else no longer believed the stories she told about her relationship with Donny and how he would whisk her away on vacation excursions.

When I entered Kinloch Park in 1972, there was a slightly larger group of black kids whom I did not know previously and we became more aware of Cuban American language and culture through our peers. There were several black teachers. I developed an interest in the sciences in large part because of my black female science teacher, Mrs. Bradshaw, whom I maintained a relationship with long after I left the school. She was clearly brilliant. In a different life time, she would have probably been a doctor (she wanted to be a gynecologist), overcoming the racial and gendered obstacles of getting into medical school in those years. But she was passionate about teaching and loved science. She spent a lot of time with me working on experiments, helping me to develop a project which I entered into the science fair. I won a prize for a truly bizarre idea,

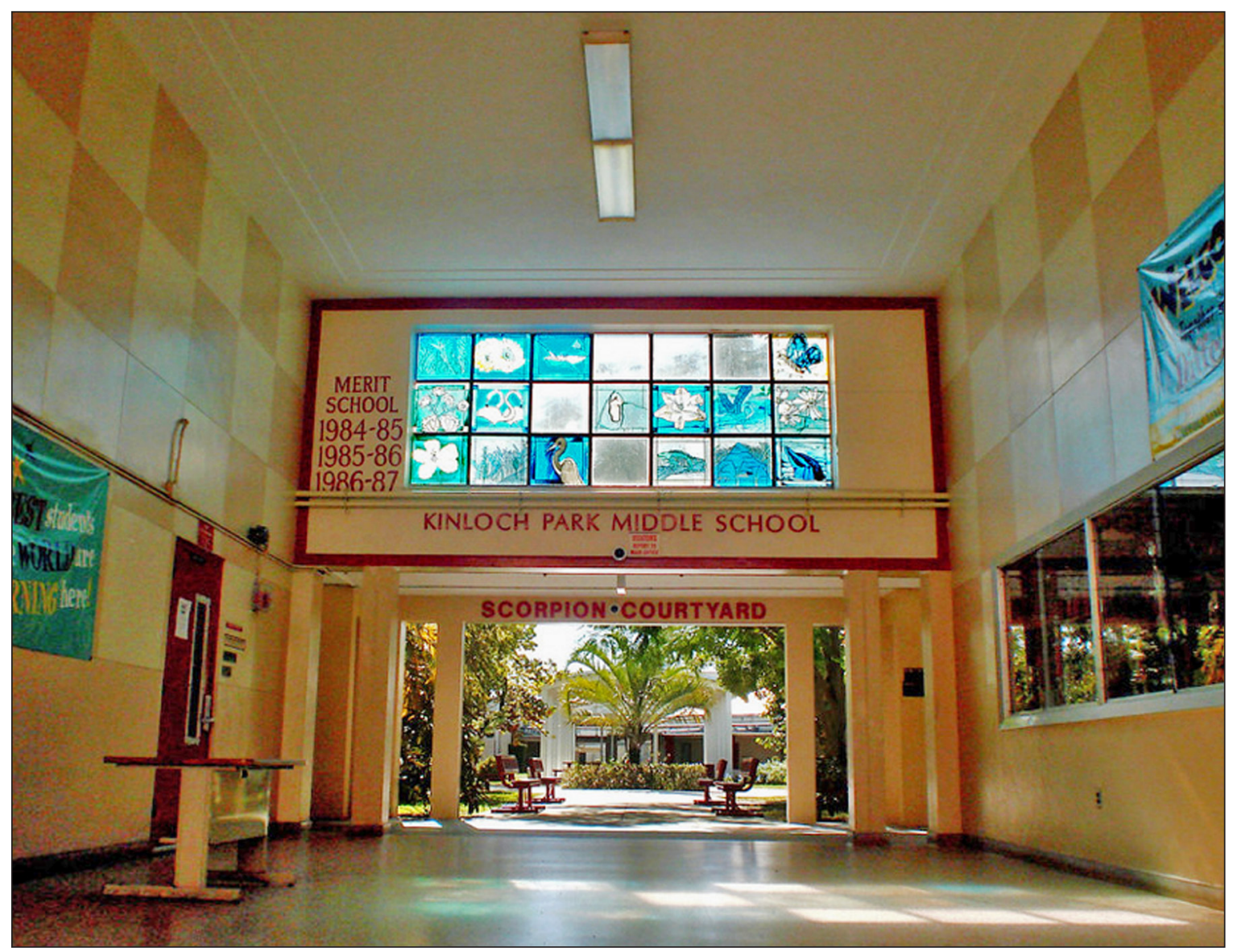

Kinloch Park Elementary School. Photo credit www.kpmschool.com/. 
which I entitled: "Intra-cavitary infusion of Radioactive Silver"-a dental project. She nominated me for a program for science students tied to the University of Miami, but I was not allowed to enter despite my very good grades. I recall her trying to carefully explain to me what she perceived to be racism behind this decision. She took a lot of time with me, having very frank conversations about a variety of life topics, in a way that adults do not normally talk to kids.

For high school my parents gave me the choice of either continuing within the school district I was in and going to Miami High or to stay closer to home and attend Miami Edison. I wanted to go closer to home. Crime was starting to tick up in our Allapattah neighborhood-we had experienced a couple of home burglaries, and my parents also wanted more space, so we moved to El Portal. Again, we found the neighborhood in transition, as whites were moving out and blacks were moving in during the late 1970s. The area that we lived in is just above what is now called Little Haiti. The adjacent Miami Shores was still almost all white. Miami Edison was also in transition. It had become predominantly African American, but still had a significant minority of white kids who came mostly from Miami Shores and a few from El Portal. I knew most of them and was friends with many because I was an honors student, and they were overrepresented in honors classes. Much of our socializing took place at school, however. We rarely visited each other's houses, unless it was attached to some extracurricular activity.

At Miami Edison, I had some outstanding teachers and some not so great ones. I lost my interest in science, largely because of a horrible physics class. But, I also kept busy in too many activities and organizations to give a full list-including the band, newspaper, and student government. I had a special relationship with one of the guidance counselors, who we called Mrs. G., who was also the advisor of student government. As Student Government President, I came to meet Dr. Dorothy Fields, who at the time was a school librarian. I invited her to be the speaker at the annual open house during my senior year. She was then in the early stages of starting what became the Black Archives and Research Foundation of South Florida. No one, she noted in her powerful presentation to us, knew there was such a thing as black Miami history. Her remarks left a lasting impression on me about the importance of archival research.

I inhabited different parts of Miami as a result of the various activities that I participated in. Most prominently, my family attended (and continues to) the Historic Mt. Zion Baptist Church on Northwest $9^{\text {th }}$ Street

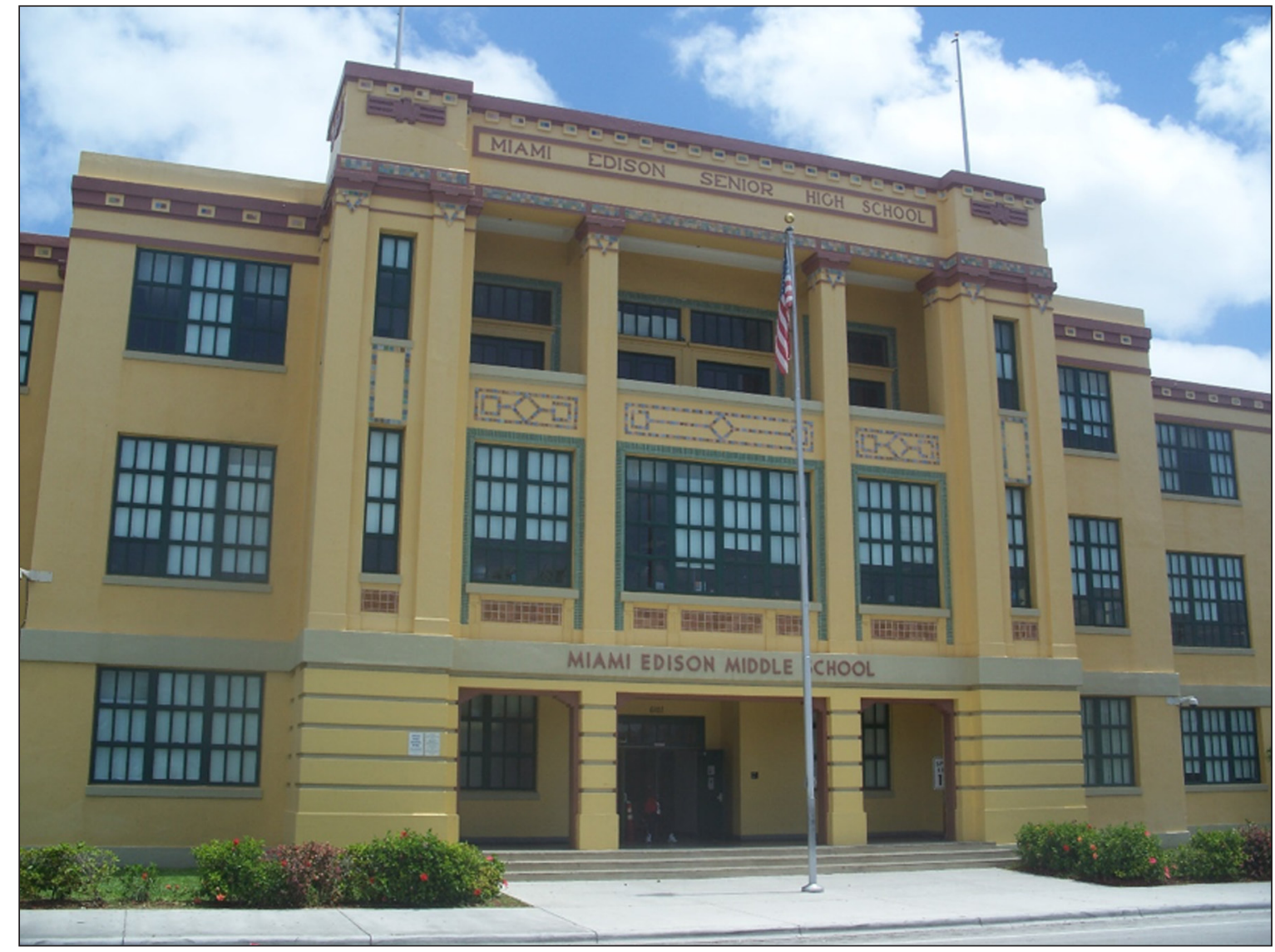

Miami Edison Senior High School building, which now houses Miami Edison Middle School. 
and Northwest $3^{\text {rd }}$ Avenue in Overtown. The church is as old as the city of Miami and, though now only a glimmer of its former self, it has played an important role in black Miami's history. I grew up with Reverend Edward T. Graham as the pastor for my early childhood. Reverend Graham also served on the Metro-Dade County Commission. He was a vice-mayor and served as the interim mayor at one time. During his term Mt. Zion was vitally engaged in black politics in the city. I learned a lot of black culture at Mt. Zion. I read black literature and memorized black poetry-almost none of which was taught in the schools I attended. I learned oratory and competed in oratorical contests, which meant I had to learn how to write and deliver speeches. And it was through Rev. Graham that I was invited to recite the "Gettysburg Address" at a prominent city event celebrating the U.S. Bicentennial.

The Overtown neighborhood surrounding Mt Zion changed during my childhood. Houses and buildings were torn down or boarded up. A highway came through that practically runs straight through the church. If you're driving on I-95 heading north from the South end, you will pass right by, it feels like almost swiping its sides. This was my first introduction to Urban Removal-or what developers call urban renewal. The displacement of people that occurred in that neighborhood was devastating. When I return home for visits now, I see new signs of life, including the restoration of the Lyric Theater, the growth of businesses and the hi-rise apartments and condominiums that are sprouting up on the edge of the American Airline Arena.

I also spent considerable time playing tennis on the courts in Moore Park on Northwest 36th Street between $7^{\text {th }}$ and $10^{\text {th }}$ avenue. ${ }^{2}$ Playing tennis got me interested in sports and the politics of race and gender. When Billie Jean King played Bobby Riggs in the "battle of the sexes" in 1973, it was the moment of my feminist awakening, as I knew women were seriously going to be doomed to subordination if she did not win the match. And I spent a lot of time engaging various volunteer projects, especially with the youth group of the National Council of Negro Women. Eunice Liberty was then the formidable president of the NCNW and retired school teacher and community leader by the time I met her. I'm sure that my work with this organization and her mentorship contributed to my interests in women's history, especially the history of the black club women's movement-which I explored as an undergraduate at Duke University. I worked on

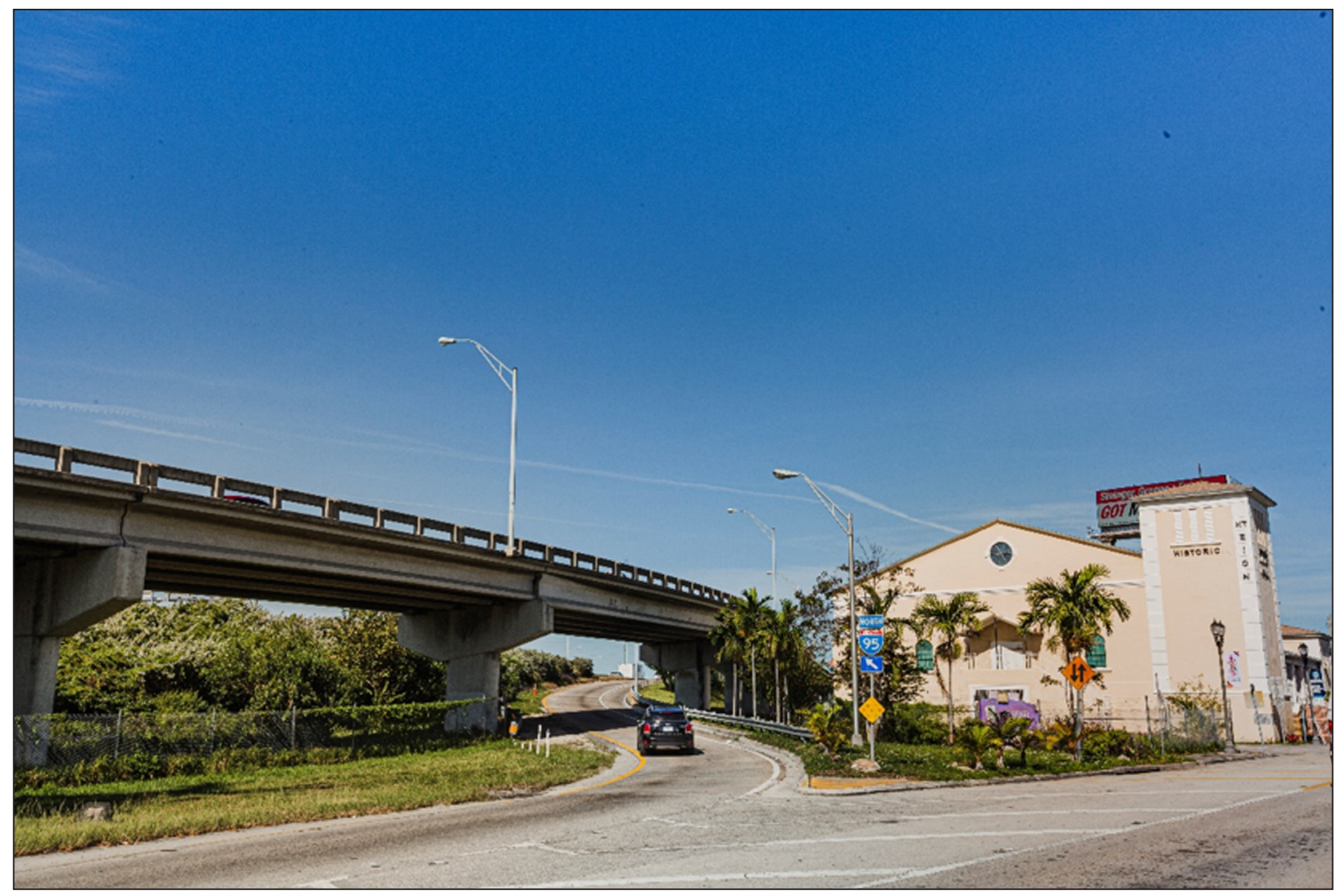

Historic Mt. Zion Baptist Church and Interstate 95. Photo credit Barry Williams.

${ }^{2}$ In 1936, the Federal Emergency Relief Association (FERA) built eleven tennis courts in Moore Park. The park remains a popular tennis spot. 
political campaigns, volunteered when Jimmy Carter ran for president, and worked on one of state senator Bob Graham's campaigns.

I do not remember any part of Miami being totally off-limits or unwelcoming in any explicit way, but there was an unspoken understanding of where one should go. There were certain hotels on Miami Beach that we went to for special or formal events. There were certain restaurants that we patronized when out-of-town guests visited. When we went to the beach, there were certain ones we would frequent for picnics-or places we could find to pull off on the side of the road along Biscayne Bay. It would be later as a young adult that I felt more comfortable exploring what is now South Beach. During its more bohemian days, before it became a tourist destination and a traffic nightmare, I would go roller-blading there with friends.

So how has Miami shaped my racial identity or my work as an intellectual? It is so deeply ingrained in who I am as a person that it is hard to say. It gave me a curiosity about history-both what I learned in school and what I learned in my community-and all the things that were left out. It made me appreciate a broader sense of what blackness represents. My extended family included people from various parts of the Diaspora, especially the Caribbean, and most especially the Bahamas. I can't think of what it means to be black and not think of this polyglot city. My interests in women's issues was piqued by observing the small and large ways women were often both in charge and also artificially subordinated because of their gender. I lived in a world in which I had all kinds of examples, role models, and mentors-many of them teachers-who nurtured me to think that I could be and do anything. I took all the gifts I was given and ran with them.

\section{Competing Interests}

The author has no competing interests to declare.

How to cite this article: Hunter, T 2020 Black Miami to Me. Anthurium, 16(1): 4, 1-7. DOI: https://doi. org/10.33596/anth.366

Published: 31 March 2020

Copyright: (c) 2020 The Author(s). This is an open-access article distributed under the terms of the Creative Commons Attribution 4.0 International License (CC-BY 4.0), which permits unrestricted use, distribution, and reproduction in any medium, provided the original author and source are credited. See http://creativecommons.org/licenses/by/4.0/. 